\title{
Boundary spanning as identity work in university business engagement roles
}

\section{Professor Lynn Martin lynn.martin@anglia.ac.uk Anglia Ruskin Faculty of Business \& Law, Anglia Ruskin University, Cambridge, CB1 1BT, UK}

\author{
Dr Pat Ibbotson, Ulster University Business, Department of Global Bus. \& Enterprise
}

Please cite as Martin, L. and Ibbotson, P., 2019. Boundary spanning as identity work in university business engagement roles. Studies in Higher Education, pp.1-13.

https://doi.org/10.1080/03075079.2019.1688281_

\begin{abstract}
The study explores how boundary-spanning is carried out to further community engagement in 15 universities of differing sizes/ages across the United Kingdom. Fifteen interviewees participated in a series of four semi-structured interviews, aged between 35-50 and with a first degree (with almost half with an MSc). One third were women. All managed their own teams and felt these were their base in negotiating difficult internal territory.. Here, boundary spanning is found to be synonymous with identity work, carried out to enable individuals to adapt to different internal and external conditions and requirements through processes of interaction and learning. It also suggests the strategic construction of identities to address perceived threats and insecurities - and the impacts of change, dominant organisational discourse and senior management on this process. Their job titles were not useful as identity badges to signal meaning, due to these being outside 'what universities are for'.
\end{abstract}

\section{Introduction}

This paper explores community engagement through the perceptions of those occupying boundary spanning roles - working within the transaction space between universities, businesses and community partners (McMillan et al, 2016), solving the 'wicked problems' that face society (Ramaley, 2016). Hence societal issues are targeted through community engagement, via cooperative research partnerships with local and national bodies (Zimmerman et al, 2019) and transformational learning programmes carried out in partnership with regional government (e.g,. Sperling et al, 2003) to innovate through the creation and sharing of knowledge (Ramaley, 2016).

Promoting socio-economic wellbeing through innovation, (HEFCE, 2017; Rossi and Rosli, 2015) has, however, been accompanied by universities needing to justify the value of their educational model in strictly financial terms (Humphreys, 2013; Ramaley, 2014). This repositioning of universities has been seen internationally (D Watson, 2008), with increasing financial constraints on universities (Jacob and Gokbel, 2018). In the U.K., monetary targets for 'third stream income' form part of the performance measurement for universities (authors, 2019). Third stream income derives from community engagement aims beyond traditional research and teaching, to meet gaps in governmental funding for institutional core activities (DIUS, 2008; Fuller et al., 2017).

Income derives from the creation, application and exploitation of knowledge and other university resources and capabilities outside academic contexts (Watson and Hall, 2015). To examine how this is achieved, this study focused on intermediaries within a group of UK universities, employed solely to deliver 'third mission' work (Fuller et al, 2017) as part of wider university investment in incubators, science parks, and new departments or centres to engage with business and industry (Hayter, 2016; Meagher and Lyall, 2013; Prysor and Henley, 2018). The sample group are not teachers, researchers or traditional administrators, but are solely employed as part of these new structures - spanning the boundary between 
academic and non-academic communities to generate diverse income streams through cooperation (e.g. Prysor and Henley, 2018). Non-income bearing community and civic engagement was carried out elsewhere in the university.

In doing so, they also span boundaries within the university since they necessarily move between different communities of administrators and academics in teaching and research. This paper focuses on how these individuals perform boundary spanning and their sense making processes as they move through diverse internal and external situations with local and national non-academic communities (Fuller et al., 2017; HEFCE, 2017). In order to understand how such professionals do so we draw on recent theories of identity work in multiple contexts (e.g. Bordogna, 2017; Prysor and Henley, 2018). Identity is constructed through 'work' via agency and the interplay with others with whom we live and work (Holland et al, 2001), to create and recreate our sense of self (Watson, 2008).

This focus is relevant given that knowledge exchange involves subtle and elusive processes, supported by "attitudinal and behavioural changes at multiple levels" (Meagher and Lyall, 2013, 411), suggesting that intermediaries need to be able to adopt different attitudes and different behaviours in relation to how others view them in changing academic situations (Deem et al, 2007; Delmestri, 2006). To explore this, an in-depth qualitative study was carried out with fifteen participants from different higher education institutions, working as intermediaries between the diverse university community and external organisations. To provide a context for the study, the next sections review previous research into boundary spanning, identity and identity work.

\section{Understanding boundary spanning as part of community engagement}

Building and sustaining strong, collaborative partnerships between universities and communities is a key goal of academic community engagement programs (Zimmerman et al, 2019). This emphasis on community collaboration addresses earlier views that higher education had drifted too far from its public purpose, especially its teaching mission (Fitzgerald et al 2016). Research into community engagement has also evolved over the last 20 years, with earlier works focusing on public service and outreach and more recent works emphasizing engagement and engaged scholarship (Fear and Sandmann, 2016).

Given that such partnerships form part of the transaction spaces between community and university, those working in these spaces may be key to "the development of networks and alliances, increasing the transference of knowledge between stakeholders, and enabling them to forge connections that inspire new initiatives" (Bordogna, 2017, 4). Being a boundary spanner means occupying more than one role at a time where movement between different domains can be understood as a 'boundary crossing' (Schein, 1971). To achieve this, boundary spanning includes a range of functional and cognitive activities to bridge relationships with external and internal stakeholders (Weerts and Sandmann 2010; Prysor and Henley, 2018). While aiming to increase university research impact, they also provide new income streams (Pilbeam, 2006).

Earlier studies have indicated the interplay of learning and communities of practice with engagement and boundary spanning. In boundary zones, "each community of practice reflects its own discourse, structure, norms and roles so that elements from both systems are always present" (McMillan et al, 2016, 24). Communities of practice "are formed by people who engage in a process of collective learning in a shared domain of human endeavour", with shared interests and a need to improve through shared interactions (Wenger and Snyder, 2000). Communities of practice are also informally organised, with self-selected membership, where members come together to work supportively and learn 
while engaging in collaboration, the participants in this study are part of a small department of other non-standard university staff, suggesting the need to explore how individuals defined their own communities of practice and how these overlapped with university and nonuniversity settings.

\section{Identity work and boundary spanning}

Here we use identity work as a basis for understanding how boundary spanning is perceived and carried out, given the flexibility of identity in responding to context (Collinson, 2003) through an ongoing and unfinished process to define self (McInnes and Corlett, 2012). To achieve this, individuals carry out identity work, through repeated activities to establish identity, as "constant and relentless achievement' of self-hood (Knights and Clarke, 2014, 337). This assumes that "humans actively engage in goal-directed action as they interact with their environment", since individuals continuously evaluate their actions in relation to their context and to their internal identity standard (Ashforth and Mael, 1989; Stets and Carter, 2012,3 ). Given the boundary spanning required in intermediary roles, identity may need to be formed and re-formed to fit multiple different contexts, often with more than one version operating at the same time (see Bordogna, 2017).

The intermediary therefore has a number of roles in creating and building effective relationships. Learning to carry out these roles is an ongoing process shaped through social interaction with others (Hatch and Schultz, 2002; Lave and Wenger, 1991). Benmore suggests that "roles can be partly prescribed but can also include some element of choice as to how new occupants interpret and fashion their roles" $(2016,1253)$, hence where roles interface with context and environment, individuals respond by shaping their role accordingly. In doing so, they construct and negotiate boundaries which enable them to make sense of the expectations of the role in order to "to simplify and order their environment" (Ashforth et al, 2008, 474) as part of the sense-making of day-to-day life (see also, Weick, 1995). As such, identity work - for knowledge intermediaries perhaps particularlyencompasses the emotional and cognitive efforts that individuals extend in order to make sense of who they are both in themselves and in relation to others (Watson, 2008).

Through social interaction, an ongoing process of "interpretation and re-interpretation of experiences" allows the individual to make sense of their role in changing contexts, time and location and align with others' expectations (Beijaard et al, 2004, 123). Here "others" include those from university, external and non-work contexts, where a view of self is based on how the individual thinks others see them (Prysor and Henley, 2018). Hence individuals use agency to orient themselves and others (Holland et al, 2001) and "conduct their everyday lives in terms of those identities" (Jenkins, 2014, 111). Perceiving and attempting to make sense of their reality, the individual therefore shapes identity to fit shared understandings shaped by societal, organisational, media and historic discourses (Ylijoki and Ursin, 2013). Individuals are therefore also group members with obligations to align with the group (Tajfel $\&$ Turner, 1986) through roles which emerge and are learned through interaction (Lave and Wenger, 1990).

Issues may arise when identities are 'dependent on others' judgments, evaluations and validations of the self and these can never be fully anticipated, let alone controlled" (Knights and Clarke, 2014, 336). They are also subject to environmental shifts, the judgments of other people (Collinson, 2003) ; the impacts of power-relations (Brown and Lewis, 2011) and to implicit organizational pressures, e.g. via institutional discourses about 'worth' or value (Laine et al, 2016). 
One way to make sense to others is through an "identity badge", which is well known, long established and taken-for-granted (Collinson, 2003; Grant et al, 2014). Hence, identifying as a doctor or a teacher immediately conveys meaning and individuals use these same terms in their home contexts to explain 'who they are', allowing the individual to define themselves by their occupation in a range of situations and contexts (Collinson. 2003). The identity badge helps to bolster an identity which may be felt to be vulnerable, especially during situations of organisational or environmental change (Ashforth et al., 2008; Collinson, 2003; Knights and Clarke, 2014). Similarly, it signals an individual's worth to others, while simultaneously confirming (and managing) what others might expect from them in their role (Weick et al, 2005). The importance of being accepted and validated by others is important for those in newly created roles, such as knowledge intermediary, for which there are few extant historical or institutional models. These perspectives on identity work and identity badges provided useful themes in the interviews as discussed below.

\section{Method}

This in-depth qualitative research focused on how participants viewed and explained their boundary spanning activities, how they felt others regarded them and their role inside and outside the institution. This included the stories they told about their role and how-or if identity badges were used to support identities in different situations. The qualitative methodology was selected for its appositeness when exploring "the subjective point of view of individuals operating within a specific frame of meaning" (Berkovich and Wasserman, 2017, 5).

Drawing on Berkovich and Wasserman $(2017,6)$, the research methods worked from the assumption that individuals form stories to make sense of their experience, as narratives reflect individuals' identity and its relations to community or social structures. Interviews were carried out in locations favoured by the participants (in the workplace or external to it) taking 50-120 minutes, recorded for later transcription. Collecting these provided "a connected set of statements, concepts, terms and expressions which constitutes a way of talking or writing about a particular issue" (Watson, 2008, 113). Participants were knowledge exchange managers in 15 universities across the United Kingdom, found through their membership of professional associations for knowledge exchange and by a snowball method, via recommendation and chance encounter. The final sample of 15 participants agreed to participate in a series of 4 semi-structured interviews, which provided "a rich source of information on the phenomenon being investigated" (Berkovich and Wasserman, 2017, 5). This purposive sample is shown in Table 1

(Table 1 about here)

Interviewees were asked to tell their own story of 'how things worked' in their institution, defining their role (how it was described and what it meant to them), using stories and narrative to emphasise or support meaning as part of their reflective sensemaking of day-today experience (Weick, 1995), important in constructing and understanding identity (Degn, 2015) by "adopting and personally transforming collectively maintained stories" (Ylijoki and Ursin, 2013, 1137), Through discourse, "subjective meanings and experience" allowed the individual to form an identity presenting who they are, what they represent and therefore how they should act, with organisational discourses determining status and appropriate behaviours and attitudes over time (Alvesson et al, 2008, 5-6; Brown and Lewis, 2011).

Participants were all managers with their own teams, forming part of their institution's middle-management strata, and were employed solely to support government-funded "third mission" work. Only 5 of the 15 participants were women, despite repeated efforts to identify 
more female participants. Ages varied but the majority were aged between 35-50, holding a first degree (with almost half of the respondents' having attained a Master's). Previous professional experience varied: although over $50 \%$ of participants had a background of employment in HEIs, typically working in careers and advisory services, placements and internships, others had experience in private sector organisations.

\section{Analysis}

Source data was collected using an iterative process, allowing stories to be told, retold and rationalised, with narratives emerging over time. These were supplemented by secondary data, including institutional documentation and online sources, websites and social media. Repeated interviews allowed deeper insights to emerge over time rather than relying on a 'snapshot' through a single data collection, in order to allow stories to emerge and be told and retold as individuals made sense of their own self-image.

The analysis included three stages (Berkovich and Wasserman, 2017). Firstly, the interviews were coded into basic categories of meaning, then these categories were grouped into themes; the last stage involved the development of meta themes across the group of stories which related to core aims of understanding boundary spanning. The analysis was carried out by the authors separately, with different interpretations reviewed and discussed as part of the development of metathemes. Reading and rereading the scripts from interviews allowed different aspects to emerge, including key phrases or themes and ways of telling stories to illustrate points. Both NVivo and SPSS helped the team to revisit responses in different ways, also facilitating the mapping of emerging themes and explorations of stories via their structure, content and emphasis.

\section{Findings}

During the first interviews, participants explained their job titles and roles, contrasting these with the perceived external perceptions of 'who they were' and 'what they did'. The border spanners described 'how things worked' in order to explain prevailing organisational norms and behaviours (Payne, 1991), including the detail of activities carried out, who they worked with, what they felt to be important and the issues and benefits embedded in their day-to-day roles. Themes were revisited each time, with participants encouraged to expand on these, in order to describe the value and status they felt was attributed to their 'section/department' both within and without the university. Stories emerged to explain the nature of - and extent to which - values, knowledge and resources were shared by the university, business and community stakeholders.

Participants defined themselves and explained their roles, in the context of their university, revealing potential conflicts between participant functions and 'what universities are for'and by explaining "what boundary spanning is for", demonstrating both conscious and unconscious identity work in doing so. The findings are discussed as internal and external issues or factors (Table 2), with

(Table 2 about here)

\section{Internal Identity Issues/Concerns \\ Community}

Participants began by explaining their department or team via their activities as separate, differentiating the group from others in the university 'we work with them of course but we need to respond more rapidly, more decisively'. The led a team which was their secure base when "negotiating with university issues .. mostly it's the team that help makes sense of things" (Participant 3). 


\section{Identity badge}

They explained what their job title meant as they felt it was not self-explanatory, often . Defining it in terms of what they were not (as in comments such as 'I'm not an academic'; 'I'm no teacher'; 'I'm not a paper pusher'). Previous research suggested that identity badges were important for self-definition but here participants felt that their title was not a useful identity badge. This was because their job titles were seen as outside 'normal' university activities; their function and their title did not fit dominant ideologies about the academy (Grant et al, 2014) and as such, participants often felt compelled to explain (and justify) their role frequently in meetings and when introducing themselves to new colleagues for the first time:

'So.. the first question was, 'knowledge exchange manager', what's sort of job's that then?" (Participant 10)

"There were two other universities represented and we all had different job titles, it was regarded as one of those university eccentricities by the industrial chair" (Participant 5).

Others felt the need to explain the role both inside and outside the university, given that it was "not a research, teaching or admin role" ... "in the way people anticipate if you are from a university" (Participant 13).

Unwanted identity badges were revealed, for instance as a gay man or female KM, being called on mainly to discuss related issues, rather than being viewed as a manager with wider knowledge and expertise. Two of the five women and three of the men interviewed described 'being typecast' as specialists on gender, regardless of the context. Both felt this damaged their identity as knowledge exchange specialists and as business experts. Having worked to build up a professional identity as intermediaries, as managers and as business specialists, identifying them firstly or solely by their gender or sexual preference was perceived as limiting and potentially diminishing of the 'other' identities they had constructed (Ooms et al, 2018; Sherer and Zakaria, 2018). Others, too, were seen solely as subject specialists, even when they had worked successfully across the university for some time (Grant et al, 2014) "it's hard for them (senior staff) to see me as a business person given my biochemistry background" (Participant 3).

At each institution, participants felt that a lack of understanding of their roles and their value was embedded in the systems of the institution, including bureaucratic processes, risk aversion, and adherence to obsolete ways of doing things. These adverse characteristics were in turn seen by participants as evidence of the presence of outdated institutional values, embedded in former models of the university system, indicative of an organisational discourse which attributed higher value and priority to other academic activities (Laine et al, 2016).The problem, as expressed below, was understood to be rooted in a lack of clarity about the role and function of knowledge exchange intermediaries:

"The University has been around a long time.. it's got very set ideas about what its professors are for, what teaching staff do and what managers and administrators are for... so we don't really fit. The professors think we are admin staff and the admin staff don't see us as part of their bureaucracy" (Participant 1). 
".. the Deans are focused on teaching and issues such as student progression, our work is outside most people's view of what a university is for ". (Participant 11)

"We are neither one thing .. nor the other.... We are called managers but the managers in faculties don't see us as their equals" (Participant 4)

There was deep frustration with how things were done, the bureaucracy and delays encountered; the lack of recognition and status for their actions and ideas; the lack of understanding of them, their roles and 'who they were'. A recurring theme was the slowness of academic response to queries and the low priority given to their knowledge exchange work:

"They are on a different timeline to ... us" (Participant 15)

"They just operate in a different way, there's no urgency, so weeks can go by before they deign to respond" (Participant 4).

Responsibility-Authority Paradox; identity threats

Responsibilities and accountabilities were felt to be high in terms of income targets but power/authority over situations was felt to be low. For example, disappointing Higher Education Business and Community Survey returns (and subsequent lower status or reduced government funding) caused problems due to awareness across the institution of low achievement of goals and targets.

Without discussion, senior managers in half of the institutions responded by reorganising and extending the intermediaries function. In four universities, consultants had been engaged to try to identify why progress was slow and why targets had been missed, without discussion internally. These actions confirmed participants in their view that they were not recognised or valued, and they expressed views showing that their identity was vulnerable:

" The consultant had a long list of names to talk to and came to us at the end of week 3. He knew nothing about us or what we do so it was very off-putting ... we were invisible.... We had to really work hard to put our case forward and to show who we were..." (Participant 14)

Other threats to identity included the varying fortunes of their senior manager. In one university, the senior manager with responsibility for enterprise was effectively a side-lined middle manager who was seen as having no power or authority.

“..we are ... reflections of him, he's seen as weak and easy to ignore so we are too. You have to work to get people to see you for yourself .... and as valuable" (Participant 9)

This lack of status associated with the senior manager was seen and responded to by others in their organisation.

"With the outside business, you're all business too, but even when the prospects are good externally you can't get any support... so you're keeping up a 'sales face' outside and grovelling inside". (Participant 12).

However, in other institutions, the reverse was also true. A senior manager who was perceived as effective and powerful by others in the university transferred that perception onto her team. 
"It's great having [the DVC] in our corner - she's a real bruiser and as other people see you as having influence ...it's great for us because we are seen as protected and as people you don't mess with" (Participant 11).

Participants therefore aligned their position in the organisation and how they were perceived with the profile/status of 'their' senior manager. This alignment could enhance or undermine an individual's professional identity depending on how others viewed the senior manager; negative perceptions meant identity work to bolster identity and emphasise their value to others, while positive perceptions meant identity work to support the view of them as powerful and effective individuals.

Boundary spanning internally was often felt to be less successful and more time consuming than external work, primarily because it was perceived to be of low value by university colleagues, threatening the identity of participants. In response, participants explained the measures they used internally to support and promote their roles. This was seen as an ongoing struggle, to counter the fixed structures and traditional mindsets within universities where their roles were not accepted.

"You're always starting again to establish yourself internally... a teacher or a researcher has an accepted role and value, it's taken for granted because everyone understands it. It can never be taken for granted in this role..(Participant 14).

\section{External Identity issues/concerns}

At each interview, participants were asked to bring their diaries (both on- and/or offline) to talk about the past week, as a prompt for discussion of the types of engagement they had carried out and to encourage storytelling. These forms of engagement included:

- Small firm associations / Small firm owners

- Technology incubator

- Formal meetings with senior corporates, local government and regional bodies

- Women's business association

- Asian business association

- Football club meetings

- Financial sector meetings at bank headquarters

- Property association meeting

- Regional health trust meeting, formal and informal

\section{Learning and community}

Working externally meant engaging in a wide range of different contexts to deliver knowledge exchange (Rossi and Rossli, 2015). This included learning, partly to 'fit' in very varied environments and partly to achieve joint bids for funds. These showed the mixture of agency and interaction suggested by Holland et al, (2001). Here groups came together in temporary alliances to achieve joint goals

"I learned a lot about how to engage (in the Council chamber) .. by watching others" (Participant 15)

"We are friendly but not friends - we just came together to get the money and really worked as a team, I learned so much in that process.." (Participant 10)

\section{Face changing/identity switching}

Externally, participants reported using the phrase, 'I'm from the university' or some similar expression, as they felt that their job title did not convey the nature / responsibility of the 
work they did to the people with whom they engaged. In particular, participants used storytelling to enable fit when explaining who they were, their level of expertise/knowledge and the role they performed

"If they are Oxbridge you play up the connections and the research.. if they didn't go to university or they went to a post-1992, then 'practical value' ...(Participant 1)

"You have to present yourself in a way to make sense to them ... universities and the ways they work can be a bit of a mystery externally .." (Participant 7)

"Most people are baffled by the Business Development title because they don't connect universities with 'real business'... they think the government just gives them money" (Participant 14)

These different interactions also required different masks to be worn and identities to be displayed:

"Different people have different reasons to talk to you,.. you can't just trot out the same old stuff with them all, you've got to try to be like them... " (Participant 15)

"The bank used to be very macho, but it's changed now there are more women so there's less banter and more conversation, you just have to go with the flow and adapt yourself to fit in working with them" (Participant 12).

Identity switching was indicated by female participants, who explained the difficulties of fitting into long established all-male groups, especially in engineering contexts.

"It's always a bit difficult, you can present yourself as a ladette, you know more macho than the men, but it's a fine line. Most times you have to present your professional side, be smart but not 'overly' sexy... and do extra work around it until finally you're accepted as an 'honorary' man, then things work OK” (Participant 5)

\section{Meeting expectations through identity alignment}

The process of seeking alignment with perceived expectations was sometimes an 'unconscious' undertaking, with participants reflecting on their previous need to carry out identity work to ensure that strong relationships were developed. This was also carried out very deliberately, however, to ensure a connection was made, with. significant preparation beforehand in order to support the image being portrayed, working out the sort of approach (banter, formality, one of the lads etc) and maintaining that approach in conversation and in online/offline communications. This was clearly evidenced in the football 'homework' carried out to 'strike the right note' with a particular external senior manager.

"You can't be the same at a football club meeting as you are at the formal meetings with the health trust... I'm not a football fan but I've had to be one for this contract, so I do my homework and join in the banter," (Participant 3)

In working outside HEIs, participants talked about 'being' the sort of person others could relate to or do business with, referring to the perceived need to adopt a different persona or to align their persona with those they were meeting, in order to create and maintain strong working relationships. All expressed views about this through phrases relating to the need to 'fit in'. This need to 'be' someone in order included the need for participants to present as 
'the sort of person ... they expect to work with' (Participant 9); to 'be relatable ... so you can discount views of the university as stuck up or stuffy' (Participant 6); to 'be the sort of person they feel comfortable with' (3 participants) ; to 'be like them' (Participant 9), and to 'be seen to be practical and business-like' (Participant 1). This pressure to reflect and embody external attitudes and behaviours, was explained as their mode of operation to ensure that successful engagement could occur.

\section{Discussion}

This paper explored how boundary spanning occurs in the context of one aspect of community engagement and found that this was carried out through identity work, evidencing "the complex relationships between the personal and the professional" in the daily work life of the sample group (Pick et al, 2017, 1188). Being a "boundary spanner" called on the participants to coordinate, facilitate and service collaboration between diverse interests, bodies and agencies (Bordogna, 2017; Williams 2013) and they did so through identity work. The study therefore adds to the growing bodies of work both on identity and on knowledge exchange, suggesting that here boundary spanning is synonymous with identity work.

The study supports previous research exploring identity work as a route to deal with complexity in interpreting role and forming identity (Bardon et al, 2017; Harding et al, 2014). Participants identified themselves as occupying middle ground, fulfilling an uncertain role situated between different levels and types of staff within their own institutions, and continually in search of the elusive recognition and approval of senior managers and other stakeholders via identity work (Thomas and Linstead, 2002).

Hence identity work depended on the way others saw them - and the world. Requiring internal recognition in order to form relationships, the individual also needed to understand and respond to dominant organisational discourses within the university (Bardon et al, 2017). This was seen in the use of storying of identity to emphasise their role. Internally, storytelling allowed participants to claim value and to try to fit what they felt the university expected; externally, this enabled the achievement of a good fit with others' expectations (Knights and Clarke, 2014; McInnes and Corlett, 2012).

Participants also felt displaced by their role "not fitting" with the core values of an institution, especially where these were embedded in a traditional view of "what universities and professors were for" (see Laine et al, 2016). Identity work was thus carried out to counter this vulnerability, influenced by "personal interactions with and expectations of significant others" together with "broad changes to organisational cultures and institutional demands" (Pick et al, 2017, 1188)

Given their hybrid role, both inside and outside of the academy, identity work provided a route for boundary spanning, where identities were formed and supported by iterative social interaction in different settings (Hatch and Schultz, 2002) and agency was evident in efforts were exerted to deal with changes and to respond to others' views of them (Holland et al, 2001; Knights and Clarke, 2014). In doing so, managers carried out ongoing identity work to be deemed appropriate across a range of "others"” in order to form relationships to support knowledge exchange (Alvesson and Wilmott, 2002; Laine et al, 2016).

Job titles did not work as effective identity badges (Ashforth et al 2008) as they required explanation and justification from participants rather than conveying readily understood meaning (Collinson, 2003). Where "badging" did occur it was often counter to the participants' preferences, being based on outdated aspects of their subject knowledge or on 
them being female, suggesting a need for further research into attitudes towards gender in these institutions (Ooms et al, 2018; Sherer and Zakaria, 2018).

Contrary to other studies, perceived threats could not therefore be mitigated by a selfexplanatory identity badge, so other actions were required to bolster identity (Collinson, 2003; Knights and Clarke, 2014). Together with embedded and tacit discourse on the role of a university and the "proper" work for people within it, these had marginalising effects on participants (Delmestri, 2006). The role of senior leadership was clearly seen here, in that participants based their own status and identity on the fortunes of their senior manager. Powerful senior managers supported perceptions of powerful subordinate identities and vice versa.

Externally different personas dealt with different situations and varying customers, showing the flexibility of identity in responding to change and to context (Collison, 2003). In order to carry out their roles as boundary spanners, they carried out identity work, routinely, day-today and in each situation. They recognised their adoption of other personas and explained them as vital to be able to work externally, but were also keen to stress that this was 'normal' and that, in the words of Participant 2,

"it's not about ... misleading people... it's presenting a version of yourself they [external ] can relate to and see themselves working with"

Despite the strategies to transform the mission of universities and to re-imagine how universities work (see Badley, 2016; Fuller et al, 2017; Morphew et al, 2018), the experience of these participants suggests that the debate about "what universities are for" remains unresolved, especially in the context of what community engagement 'means', suggesting that clarity and consistency are needed for universities to embed external working successfully.

Other future research might include (a) how organisational discourses impact on identity construction for female and gay knowledge exchange managers, given the "typecasting" seen here (b) the identify formation and maintenance carried out by those in organisational hinterlands, operating internally and externally (Svenningsson and Alvesson, 2003; Watson, 2008) (c) the impact of senior managers on identity given the participants' view of power transferred or lost. Also, the study involved a small sample of university managers within a particular function. While this detailed study provided a rich data source, wider sampling and alternative methods will undoubtedly provide further perspectives.

\section{References}

Alvesson, M., \& Willmott, H. (2002). Identity regulation as organizational control: Producing the appropriate individual. Journal of Management Studies, 39(5), 619-644.

Alvesson, M., Lee Ashcraft, K., \& Thomas, R. (2008). Identity matters: Reflections on the construction of identity scholarship in organization studies. Organization, 15(1), 5-28.

Ashforth, B. E., \& Mael, F. (1989). Social identity theory and the organization. Academy of Management Review, 14(1), 20-39.

Ashforth, B. E., Harrison, S. H., \& Corley, K. G. (2008). Identification in organizations: An examination of four fundamental questions. Journal of Management, 34(3), 325-374. 
Badley, G. (2016). The pragmatic university: a feasible utopia?. Studies in Higher Education, 41(4), 631-641.

Bardon, T., Brown, A. D., \& Pezé, S. (2017). Identity regulation, identity work and phronesis. Human Relations, 70(8), 940-965.

Beijaard, D., Meijer, P. C., \& Verloop, N. (2004). Reconsidering research on teachers' professional identity. Teaching and teacher education, 20(2), 107-128.

Benmore, A., (2016). Boundary management in doctoral supervision: How supervisors negotiate roles and role transitions throughout the supervisory journey. Studies in Higher Education, 41(7), pp.1251-1264.

Berkovich, I. and Wasserman, V., (2017). Exploring narratives of non-faculty professionals in neoliberal higher education: a cultural appropriation perspective on librarians. Studies in Higher Education, 1-13. http://doi.org/10.1080/03075079.2017.1413081

Bordogna, C.M., (2017). The effects of boundary spanning on the development of social capital between faculty members operating transnational higher education partnerships. Studies in Higher Education,1-13., http://doi.org/ 10.1080/03075079.2017.1349742

Brown, A. D. (2015). Identities and identity work in organizations. International Journal of Management Reviews, 17(1), 20-40.

Brown, A. D., \& Lewis, M. A. (2011). Identities, discipline and routines. Organization Studies, 32(7), 871-895.

Collinson, D. L. (2003). Identities and insecurities: Selves at work. Organization, 10(3), 527547.

Deem, R., Hillyard, S., Reed, M., \& Reed, M. (2007). Knowledge, higher education, and the new managerialism: The changing management of UK universities. Oxford University Press.

Degn, L. (2015). Identity constructions and sensemaking in higher education-a case study of Danish higher education department heads. Studies in Higher Education, 40(7), 1179-1193.

Delmestri, G., (2006). Streams of inconsistent institutional influences: Middle managers as carriers of multiple identities. Human Relations, 59(11), pp.1515-1541.

DIUS, Department for Innovation, Universities and Skills (2008) Innovation Nation, Edinburgh, Her Majesty's Stationery Office.

Fear, F.A. and Sandmann, L.R., (2016). The" New" Scholarship: Implications for Engagement and Extension. Journal of Higher Education Outreach and Engagement, 20(1), pp.101-112.

Fitzgerald, H. E., Bruns, K., Sonka, S., Furco, A., \& Swanson, L. (2016). The centrality of engagement in higher education. Journal of Higher Education Outreach and Engagement, 16(3), 7-28.

Fuller, D., Beynon, M., \& Pickernell, D. (2017). Indexing third stream activities in UK universities: exploring the entrepreneurial/enterprising university. Studies in Higher Education, 1-25, http:/doi.org/10.1080/03075079.2017.1339029 
Grant, A.M., Berg, J.M. and Cable, D.M., (2014) Job titles as identity badges: How selfreflective titles can reduce emotional exhaustion. Academy of Management journal, 57(4), pp.1201-1225.

Harding, N., Lee, H. and Ford, J., 2014. Who is 'the middle manager'?. Human Relations, 67(10), pp.1213-1237.

Hatch, M. J., \& Schultz, M. (2002). The dynamics of organizational identity. Human Relations, 55(8), 989-1018.

Hayter, C. S. (2016). A trajectory of early-stage spinoff success: the role of knowledge intermediaries within an entrepreneurial university ecosystem. Small Business Economics, 47(3), 633-656.

HEFCE, (2017), Knowledge exchange funding, http://www.hefce.ac.uk/ke/heif/

Holland, D.C., Lachicotte Jr, W., Skinner, D. and Cain, C., (2001). Identity and agency in cultural worlds. Harvard University Press.

Humphreys, D. (2013). Success after college: What students, parents, and educators need to know and do. Liberal Education 99 (2). Accessed at https://aacu.org/publicationsresearch/periodicals/success-after- college-what-students-parents-and-educators-need.

Jacob, W.J. and Gokbel, V., 2018. Global higher education learning outcomes and financial trends: Comparative and innovative approaches. International Journal of Educational Development, 58, pp.5-17.

Jenkins, R. (2014). Social identity. $4^{\text {th }}$ edition, Routledge.

Knights, D., \& Clarke, C. A. (2014). It's a bittersweet symphony, this life: Fragile academic selves and insecure identities at work. Organization Studies, 35(3), 335-357.

Laine, P.M., Meriläinen, S., Tienari, J. and Vaara, E., (2016). Mastery, submission, and subversion: On the performative construction of strategist identity. Organization, 23(4), 505524.

Lave, J., and E. Wenger. 1991. Situated learning: Legitimate peripheral participation. Cambridge: Cambridge University Press.

McInnes, P., \& Corlett, S. (2012). Conversational identity work in everyday interaction. Scandinavian Journal of Management, 28(1), 27-38.

McMillan, J., Goodman, S., \& Schmid, B. (2016). Illuminating “Transaction Spaces" in Higher Education: University-Community Partnerships and Brokering as "Boundary Work". Journal of Higher Education Outreach and Engagement, 20(3), 8-31.

Meagher, L., \& Lyall, C. (2013). The invisible made visible: using impact evaluations to illuminate and inform the role of knowledge intermediaries. Evidence \& Policy: A Journal of Research, Debate and Practice, 9(3), 409-418.

Morphew, C. C., Fumasoli, T., \& Stensaker, B. (2018). Changing missions? How the strategic plans of research-intensive universities in Northern Europe and North America balance competing identities. Studies in Higher Education, 43(6), 1074-1088. 
Ooms, W., Werker, C., \& Hopp, C. (2018). Moving up the ladder: heterogeneity influencing academic careers through research orientation, gender, and mentors. Studies in Higher Education, 1-22. https://doi.org/10.1080/03075079.2018.1434617

Payne, S. (1991), "A Proposal for Corporate Ethical Reform: The Ethical Dialogue Group, "Business and Professional Ethics Journal, 10(1), 67-88.

Pick, D., Symons, C. and Teo, S.T., (2017). Chronotopes and timespace contexts: academic identity work revealed in narrative fiction. Studies in Higher Education, 42(7), 1174-1193.

Pilbeam, C. (2006). Generating additional revenue streams in UK universities: An analysis of variation between disciplines and institutions.. Journal of Higher Education Policy and Management, 28(3): 297-311.

Prysor, D. and Henley, A., (2018). Boundary spanning in higher education leadership: identifying boundaries and practices in a British university. Studies in Higher Education, 43(12), 2210-2225.

Ramaley, J. A. (2014). The changing role of higher education: Learning to deal with wicked problems. Journal of Higher Outreach and Engagement. 18 (3), 7-21.

Ramaley, J., (2016). Collaboration in an era of change: new forms of community problemsolving. Metropolitan Universities, 27(1), pp.3-24.

Rossi, F., \& Rosli, A. (2015). Indicators of university-industry knowledge transfer performance and their implications for universities: evidence from the United Kingdom. Studies in Higher Education, 40(10), 1970-1991.

Schein, E.H., 1971. The individual, the organization, and the career: A conceptual scheme. The Journal of Applied Behavioral Science, 7(4), pp.401-426.

Sherer, M. J., \& Zakaria, I. (2018). Mind that gap! An investigation of gender imbalance on the governing bodies of UK universities. Studies in Higher Education, 43(4), 719-736.

Sperling, R., Wang, V.O., Kelly, J.M. and Hritsuk, B., 2003. Does one size fit all? The challenge of social cognitive development. Michigan Journal of Community Service Learning, 9(2), p.5.

Stets, J. E., \& Carter, M. J. (2012). A theory of the self for the sociology of morality. American Sociological Review, 77(1), 120-140.

Sveningsson, S. and Alvesson, M., (2003). Managing managerial identities: Organizational fragmentation, discourse and identity struggle. Human relations, 56(10), pp.1163-1193.

Tajfel, H. \& Turner, J.C. The social identity theory of intergroup behaviour. In S. Worchel \& W.G. Austin (Eds), Psychology of inter-group relations. Chicago, IL: Nelson-Hall, 1986, 724.

Thomas R and Linstead A (2002) Losing the plot? Middle managers and identity. Organization 9(1), 71-93.

Watson, D., 2008. The university in the modern world: Ten lessons of civic and community engagement. Education, Citizenship and Social Justice, 3(1), pp.43-55. 
Watson T. J. (2008) Managing identity: Identity work, personal predicaments and structural circumstances. Organization 15(1), 121-143.

Watson, D. and Hall, L., (2015). Addressing the elephant in the room: Are universities committed to the third stream agenda. International Journal of Academic Research in Management, 4(2), pp.48-76

Weerts, D.J., and L.R. Sandmann (2010). Community Engagement and Boundary Spanning Roles at Research Universities The Journal of Higher Education 81 (6), 702-27.

Weick, K. E. (1995). Sensemaking in organizations. Thousand Oaks, CA: Sage.

Weick, K.E., Sutcliffe, K.M. and Obstfeld, D., (2005). Organizing and the process of sensemaking. Organization science, 16(4), pp.409-421.

Wenger, E.C. and Snyder, W.M., (2000). Communities of practice: The organizational frontier. Harvard business review, 78(1), pp.139-146.

Williams, P. (2013) We Are All Boundary Spanners Now? International Journal of Public Sector Management 26 (1), 17-32.

Ylijoki, O. H., \& Ursin, J. (2013). The construction of academic identity in the changes of Finnish higher education. Studies in Higher Education, 38(8), 1135-1149

Zimmerman, E.B., Haley, A., Creighton, G.C., Bea, C., Miles, C., Robles, A., Cook, S. and Aroche, A., 2019. Assessing the Impacts and Ripple Effects of a Community-University Partnership: A Retrospective Roadmap. Michigan Journal of Community Service Learning, 25(1), pp.62-76. 